\title{
STUDY OF PREVALENCE OF SPONTANEOUS BACTERIAL PERITONITIS IN CIRRHOSIS OF LIVER WITH ASCITES
}

\author{
Sreenivasulu $V^{1}$, Bheemasenachari $M^{2}$
}

${ }^{1}$ Associate Professor, Department of Medicine, Anantapur Medical College, Anantapuramu. ${ }^{2}$ Associate Professor, Department of Medicine, Anantapur Medical College, Anantapuramu.

\begin{abstract}
\section{BACKGROUND}

Cirrhosis of Liver is the common hepatological disorder in clinical practice. The development of Ascites is a marker of Prognosis. Spontaneous Bacterial Peritonitis is responsible for the deterioration of the condition. Without prompt diagnosis, the diagnosis and treatment of infected Ascites may be delayed, leading to death. Study was conducted in 50 patients of Govt. General Hospital, Anantapuramu, to determine the prevalence of spontaneous bacterial peritonitis in Cirrhosis of liver with Ascites patients. Of these 50 patients, 9 patients (18\%) showed features of SBP, 7 patient's $(77.7 \%)$ PMN count was $>250 / \mathrm{mm}^{3}, 2$ patient's (22.3\%) culture was positive for E. coli. All cases with abdominal pain, tenderness and altered sensorium were having features of SBP. Study showed SBP more common in advanced liver disease. Presence of Jaundice had no significance, but the degree of Jaundice is an indicator of SBP. Study shown Cirrhotic patients with constitution of symptoms should be screened for SBP and started on Antibiotic therapy so that mortality can be reduced.
\end{abstract}

\section{KEYWORDS}

Spontaneous Bacterial Peritonitis; Cirrhosis, Ascites.

HOW TO CITE THIS ARTICLE: Sreenivasulu V, Bheemasenachari M. Study of prevalence of spontaneous bacterial peritonitis in cirrhosis of liver with ascites. J. Evolution Med. Dent. Sci. 2016;5(44):2720-2724, DOI: 10.14260/jemds/2016/636

\section{INTRODUCTION}

Cirrhosis of Liver is the common hepatological disorder seen in clinical practice. Ascites is the consequence of portal hypertension, which is a characteristic clinical feature of cirrhosis. The development of ascites is a marker of prognosis in liver cirrhosis, as it indicates a reduction in 1- and 5-year survival rates by $15 \%$ and $23.5 \%$, respectively. ${ }^{1}$

One of the predisposing factors which is responsible for hepatic encephalopathy and subsequent deterioration in the condition of cirrhosis patient is appearance of Spontaneous Bacterial Peritonitis (SBP). The terminal event in these patients is Hepatic encephalopathy.

The symptoms and signs of SBP are fever, abdominal pain, abdominal tenderness, rebound tenderness, altered mental status. Although $87 \%$ of patients with SBP are symptomatic at the time the infection is diagnosed, the symptoms and signs of infection are often subtle such as slight change in mental status. Without prompt paracentesis, the diagnosis and treatment of infected ascites may be delayed often resulting in death of the patient.

A single organism usually, enteric group is cultured from the ascitic fluid in majority of cases. ${ }^{2}$ Mild bacterial translocation to the mesenteric lymph nodes is a documented physiological event; however, only a few intestinal bacteria including Escherichia coli, Klebsiella pneumoniae and other Enterobacteriaceae are able to efficiently translocate from the lumen of the gut to the mesenteric lymph nodes. ${ }^{3}$ E. coli, Streptococci and Klebsiella cause most episodes of SBP and MNB in patients who are not receiving selective intestinal decontaminants.

Financial or Other, Competing Interest: None.

Submission 01-04-2016, Peer Review 26-04-2016,

Acceptance 02-05-2016, Published 01-06-2016.

Corresponding Author:

Dr. Sreenivasulu $V$,

6-4-53-1, Maruthi Nagar,

Ananthapuramu,

E-mail: drsreenivasuluvemula9@gmail.com,

srilathabheemsen@gmail.com

DOI: 10.14260/jemds/2016/636
Patients with cirrhosis are unusually predisposed to Bacterial infection because of multiple defects in Immune defense. Low ascitic fluid total protein concentrations as well as the phagocytic dysfunction associated with cirrhosis are risk factors for bacterial infection. Paracentesis itself has been proposed as a risk factor for ascitic fluid infection. ${ }^{4}$

Gastrointestinal haemorrhage and Urinary Tract Infection are under-recognized risk factors for SBP. 5

Clinical deterioration, especially fever or abdominal pain in a patient with ascites should raise the suspicion of infection and prompt a paracentesis. ${ }^{5}$

SBP is statistically more likely to be diagnosed on the first paracentesis than on subsequent taps. ${ }^{5}$

So unexplained fever, hypothermia, hypotension, encephalopathy, abdominal pain or simply unexplained clinical deterioration should be considered as indicators for diagnostic paracentesis in cirrhotics for the diagnosis of SBP. $6,7,8,9,10,11$ SBP is caused by enteric group of organisms in about $75 \%$ and the remainder by non-enteric group of organisms including anaerobes. ${ }^{12,13}$

SBP being the problem in cirrhosis with ascites, all cirrhotics should be screened for SBP with at least ascitic fluid analysis, PMN cell count and culture of ascetic fluid. To maximize survival, it is important that paracentesis is performed in all patients with ascites at the time of hospitalization. So that infection can be detected and treated promptly. ${ }^{14}$ These patients must be treated with antibiotics aggressively, as they have poor prognosis and high mortality if not treated early. The present study is taken up to find SBP in cases of ascites and find its aetiological causes, so that early diagnosis will help in early initiation of treatment of SBP leading to improvement of clinical state.

\section{AIMS AND OBJECTIVES OF STUDY}

1. To determine the Prevalence of spontaneous bacterial peritonitis and variants in patients of cirrhosis of liver with ascites.

2. To study clinical profile of spontaneous bacterial peritonitis and its variants. 


\section{MATERIALS AND METHODS}

\section{Source of Data}

This study was carried out on patients admitted to Government General Hospital, Anantapur, Govt. Medical College, Anantapur.

\section{Study Subjects}

Patients admitted for cirrhosis of liver with ascites or its complications were studied during the period from January 2015 to June 2015. All patients who were confirmed of hepatic cirrhosis with ascites by ultrasound were screened for SBP. Liver size, caudate/right lobe ratio, liver surface, echogenicity, portal vein diameter, portal vein mean flow velocity and spleen size were variables used in diagnosing cirrhosis. Total of 50 patients were studied thoroughly with regards to both history and clinical examination as per Proforma, which is attached in Annexure.

\section{METHODS}

SBP was diagnosed by following criteria. ${ }^{15,16}$ An ascitic fluid neutrophil count greater than 250 cells $/ \mathrm{mm}^{3}$ or a positive ascitic fluid culture and an absence of a primary source of infection in abdomen.

Ascitic fluid for analysis was aspirated as soon as the patients were admitted and diagnosed to be suffering from Cirrhosis of Liver before giving any antibiotics. All patients underwent paracentesis within 24 hours of admission. About $30 \mathrm{~mL}$ of ascitic fluid was tapped in each patient with aseptic precautions.

1. $10 \mathrm{~mL}$ of ascitic fluid was immediately inoculated into blood culture bottles at the bed side for microbiological analysis.

2. $10 \mathrm{~mL}$ of ascitic fluid was sent to the laboratory in sterile test tubes for conventional culture.

3. $10 \mathrm{~mL}$ of ascitic fluid was utilized for biochemical and cytological examination.

Ascitic fluid of all patients were analysed for the type of cells and cell count. Gram's stain was done in all cases. Ascitic fluid was cultured to know the presence of pathogenic organisms.

Ascitic fluid was subjected to culture in blood culture bottles, Cytological and Biochemical examination including protein, albumin, glucose and $\mathrm{pH}$. A total of $20 \mathrm{~mL}$ of ascetic fluid was inoculated, $10 \mathrm{~mL}$ was inoculated in blood broth. The broth bottle was incubated under aerobic conditions at $35^{\circ} \mathrm{C}$ for 7 days. Blind subcultures on sheep blood agar and MacConkey agar (Incubated in aerobic conditions) and in phenylethyl alcohol agar (Incubated in anaerobic conditions) were performed at 48 and $72 \mathrm{~h}$. The final report will be made after 72 hours. Both plates and broth were examined daily for visible growth. When turbidity was detected, additional subcultures were performed. On isolation the organisms were characterized by standard protocol and antibiotic sensitivity evaluated. The method adopted for statistical analysis is " $t$ test" using GraphPad calculator.

\section{Inclusion Criteria}

Cirrhosis of liver was diagnosed on the basis of clinical features suggestive of chronic liver disease. Biochemical features (Modestly raised liver enzymes, Hypoalbuminemia, reversal of albumin to globulin ratio and prolonged prothrombin time), all suggestive of chronic liver disease. Ultrasound abdomen showing features of cirrhosis of liver and portal hypertension. Upper gastrointestinal endoscopy showing evidence of portal hypertension. Liver biopsy (Wherever possible) showing features of cirrhosis.

\section{Exclusion Criteria}

\section{The following Patients Were Excluded from Study}

1. Patient who had received antibiotic within 3 weeks prior to admission.

2. Patients classified as having secondary peritonitis, which was diagnosed when one of the following features were present.

a. Selective and persistent localized abdominal pain and tenderness

b. Presence of following

3. Ascitic fluid lactic dehydrogenase concentration more than $225 \mathrm{mg} / \mathrm{dL}$.

4. Ascitic fluid glucose concentration less than $50 \mathrm{mg} / \mathrm{dL}$.

a. Isolation of more than one micro-organism in the ascitic fluid culture.

b. An evidence of an intra-abdominal surgically treatable source of infection.

5. Tuberculosis abdomen with ascites.

6. Malignancy with ascites.

\section{RESULTS AND ANALYSIS}

Total 50 patients were studied thoroughly with regards to both history and clinical examination, cytological, microbiological and biomedical tests. The observations of the study are analysed.

\begin{tabular}{|c|c|c|}
\hline Symptoms & Number of Patients & Percentage \\
\hline $\begin{array}{c}\text { Abdominal } \\
\text { distention }\end{array}$ & 50 & $100 \%$ \\
\hline $\begin{array}{c}\text { Swelling of lower } \\
\text { limbs }\end{array}$ & 19 & $38 \%$ \\
\hline Jaundice & 17 & $34 \%$ \\
\hline Fever & 12 & $24 \%$ \\
\hline Abdominal pain & 5 & $10 \%$ \\
\hline Vomiting & 1 & $2 \%$ \\
\hline Altered sensorium & 3 & $6 \%$ \\
\hline \multicolumn{2}{|c|}{ Table 1: Details of Symptoms } \\
\hline
\end{tabular}

All study subjects had free fluid in abdomen, which was mild-to-massive in degree; $24 \%$ of cases had fever, it was mildto-moderate in degree in 8 cases; it was associated with chills; $10 \%$ had abdominal pain at the time of presentation; it was vague pain, distributed all over the abdomen, lasting throughout the day. There were no relieving factors; $34 \%$ patients had Jaundice as the presenting complaints associated with yellow colouration of urine. While $6 \%$ of cases were admitted with history of altered sensorium ranging from irritability, restlessness and drowsiness. Vomiting was the presenting complaint in $2 \%$ of patients.

\begin{tabular}{|c|c|c|}
\hline Signs & Number of Patients & Percentage \\
\hline Ascites & 50 & $100 \%$ \\
\hline Icterus & 27 & $54 \%$ \\
\hline Pedal oedema & 19 & $38 \%$ \\
\hline Fever & 12 & $24 \%$ \\
\hline $\begin{array}{c}\text { Abdominal } \\
\text { tenderness }\end{array}$ & 5 & $10 \%$ \\
\hline Asterixis & 5 & $10 \%$ \\
\hline Hepatomegaly & 2 & $4 \%$ \\
\hline \multicolumn{2}{|c|}{ Table 2: Physical Signs } \\
\hline
\end{tabular}


All $(100 \%)$ the patients studied in this series had moderate-to-severe ascites; among them $18 \%$ of cases had tense ascites. Icterus was seen in 54\% of cases. Bilirubin level ranged from $0.7-24.4 \mathrm{mg} / \mathrm{dL}$. Pedal oedema was seen in $38 \%$ cases. Fever was seen in $24 \%$ of patients. Asterixis was seen in $10 \%$ of cases. Hepatomegaly was seen in $4 \%$ of cases only. These patients were in early phase of cirrhosis and was having minimal ascites. Diffuse abdominal tenderness was seen in $10 \%$ of cases.

All the cases were investigated for evidence of portal hypertension by Ultrasonography. Ascitic fluid was aspirated for diagnostic purpose in all subjects for evaluation of the cause and presence of SBP. A total of $20 \mathrm{~mL}$ of ascetic fluid was inoculated, $10 \mathrm{~mL}$ in Glucose broth at bedside and another 10 mL was inoculated in Blood broth. Remaining fluid was utilized for cytological and biochemical tests and the results are tabulated below.

\begin{tabular}{|c|c|c|c|c|c|}
\hline $\begin{array}{c}\text { Total } \\
\text { No. of } \\
\text { Patients }\end{array}$ & $\begin{array}{c}\text { Patients } \\
\text { Positive } \\
\text { for SBP }\end{array}$ & $\begin{array}{c}\text { Positive } \\
\text { by PMN } \\
\text { Count } \\
\mathbf{2} \mathbf{2 5 0 / m} \\
\mathbf{m 3}\end{array}$ & $\begin{array}{c}\text { Positive } \\
\text { by } \\
\text { Culture }\end{array}$ & Males & Females \\
\hline 50 & 9 & 7 & 2 & 9 & 0 \\
\hline \multicolumn{5}{|c|}{ Table 3: Prevalence of SBP } \\
\hline
\end{tabular}

\begin{tabular}{|c|c|c|c|c|c|}
\hline $\begin{array}{c}\text { Mode of } \\
\text { Presentation }\end{array}$ & \begin{tabular}{|c|} 
No. \\
of \\
Cases
\end{tabular} & $\begin{array}{c}\text { Positive } \\
\text { for } \\
\text { SBP }\end{array}$ & \begin{tabular}{|c|} 
PMN \\
Count \\
$>250 / \mathrm{mm}^{3}$
\end{tabular} & $\begin{array}{l}\text { Culture } \\
\text { Positive }\end{array}$ & Percentage \\
\hline With fever & 12 & 8 & 7 & 1 & $66 \%$ \\
\hline $\begin{array}{l}\text { Without } \\
\text { fever }\end{array}$ & 38 & 1 & nil & nil & $2.6 \%$ \\
\hline $\begin{array}{c}\text { Altered } \\
\text { sensorium }\end{array}$ & 3 & 3 & 2 & 1 & $100 \%$ \\
\hline Vomiting & 1 & nil & nil & nil & $0 \%$ \\
\hline \multicolumn{6}{|c|}{ Table 4: Mode of Presentation SBP Cases } \\
\hline
\end{tabular}

Among the 50 patients studied, 12 patients presented with fever, 1 presented with vomiting and 3 patients presented with altered sensorium. In 12 patients who presented with fever in 8 patients had SBP (66\%), 7 patients had PMN count $>250 / \mathrm{mm}^{3}$ (CNNA) and 1 was culture positive (MNB).

Three patients presented with altered sensorium; all the 3 patients were positive for SBP. Among these three positive cases, one was culture positive (E. coli) MNB and the rest 2 had PMN count $>250 / \mathrm{mm}^{3}$ (CNNA). Presence of Jaundice had no significance to SBP, but the degree of Jaundice is an indicator of SBP. Similarly, Ascites had no significance to the occurrence.

\begin{tabular}{|c|c|c|c|c|c|}
\hline Signs & No. of Patients & Positive SBP & $\mathrm{PMN}>250 / \mathrm{mm}^{3}$ & Culture Positive & Percentage \\
\hline Jaundice & 27 & 8 & 7 & 1 & $29.6 \%$ \\
\hline Fever & 12 & 8 & 7 & 1 & $66 \%$ \\
\hline Abdominal tenderness & 5 & 5 & 4 & 1 & $100 \%$ \\
\hline Asterixis & 5 & 3 & 3 & Nil & $60 \%$ \\
\hline Altered sensorium & 3 & 3 & 2 & 1 & $100 \%$ \\
\hline
\end{tabular}

\begin{tabular}{|c|c|c|c|c|c|}
\hline \multirow{3}{*}{ Investigations } & \multicolumn{4}{|c|}{ Outcome } & \multirow{3}{*}{$P$ value } \\
\hline & \multicolumn{2}{|c|}{ Patients with SBP } & \multicolumn{2}{|c|}{ Patients without SBP } & \\
\hline & Mean & SD & Mean & SD & \\
\hline Total Count & 15061.11 & 422.71 & 8603 & 314.28 & $<0.0001^{* *}$ \\
\hline Total Bilirubin & 6.30 & 3.47 & 2.91 & 1.38 & $<0.0001^{* *}$ \\
\hline SGOT & 182.67 & 31.56 & 175.44 & 28.51 & 0.5022 \\
\hline SGPT & 155.44 & 11.93 & 153.98 & 22.34 & 0.8553 \\
\hline Serum Creatinine & 3.24 & 1.99 & 1.28 & 0.64 & $<0.0001^{* *}$ \\
\hline AF Protein & 1.256 & 0.667 & 1.69 & 0.474 & $0.0260 *$ \\
\hline AF Cell Count & 526.67 & 206.67 & 165.05 & 6.55 & $<0.0001^{* *}$ \\
\hline
\end{tabular}

* Significant, ** Highly Significant

Comparison of investigations between the patients of SBP and patients without SBP are studied using t-test, which showed significant $p$ value in Total count $(<0.0001)$, Total Bilirubin $(<0.0001)$, Serum Creatinine $(<0.0001)$ and Ascitic fluid cell count $(<0.0001)$ and Ascitic fluid protein $(0.0260)$ which are highly statistically significant.

\section{DISCUSSION}

$18 \%$ of Ascitic subjects had Spontaneous Bacterial Peritonitis out of 50 Cirrhotic Ascitic cases presently studied. In these 7 patients had only PMN count $>250 / \mathrm{mm}^{3}$, but culture negative for any organisms. Only 2 subjects were culture positive and isolated E. coli organism on culture by $72 \mathrm{hrs}$.
In present study, the prevalence of SBP is found to be $18 \%$. Among this $18 \%$ (9 patients), 7 (77.7\%) were CNNA and 2 (22.3\%) were MNB.

In various studies, routine paracentesis has documented a prevalence of SBP of $10-27 \% \cdot 17,18,19,20,21,22,23$ Andreu et al reported a prevalence of $28 \%$, while Amarapurkar et al found it to be $22.5 \%$.

In a study involving 169 cirrhotic patients, Jarcuska et al found evidence of SBP by first paracentesis in 27 (16.0\%). Romney et al in a study involving 67 cirrhotic patients found no case of CNNA and only 10 of MNB.24

Obstein KL. ${ }^{25}$ et al in a retrospective case control study of patients with cirrhosis and ascites found, 29 (26.12\%) of 111 patients with cirrhosis were found to have SBP. 
MP Agarwal et al from Delhi studied 41 patients of cirrhotic ascites, among them 14 patients diagnosed to have SBP or one of its variants. A prevalence of $34.14 \%$.

\begin{tabular}{|c|c|}
\hline Study Series & Prevalence (\%) \\
\hline Andreu et al & $28 \%$ \\
\hline Amarapurkar et al & $22.5 \%$ \\
\hline Jarcuska et al & $16 \%$ \\
\hline Romney et al & $14.9 \%$ \\
\hline MP Agarwal et al & $34.14 \%$ \\
\hline Obstein K et al & $26.12 \%$ \\
\hline Present Study & $18 \%$ \\
\hline \multicolumn{2}{|c|}{ Table 7: Study Series } \\
\hline
\end{tabular}

\begin{tabular}{|c|c|c|}
\hline $\begin{array}{c}\text { Study } \\
\text { Series }\end{array}$ & $\begin{array}{c}\text { Mihas AA } \\
\text { Toussaint J }\end{array}$ & $\begin{array}{c}\text { Present } \\
\text { Study }\end{array}$ \\
\hline Fever & $69 \%$ & $66 \%$ \\
\hline Abdominal pain & $59 \%$ & $100 \%$ \\
\hline $\begin{array}{c}\text { Abdominal } \\
\text { Tenderness }\end{array}$ & $49 \%$ & $100 \%$ \\
\hline $\begin{array}{c}\text { Hepatic } \\
\text { Encephalopathy } \\
\text { (Altered sensorium) }\end{array}$ & $54 \%$ & $100 \%$ \\
\hline \multicolumn{2}{|c|}{ Table 8: Study of Symptoms } \\
\hline
\end{tabular}

In present study all the cases with abdominal pain, abdominal tenderness, altered sensorium were having SBP.

\section{SUMMARY}

$18 \%$ of Ascitic subjects had Spontaneous Bacterial Peritonitis out of 50 Cirrhotic Ascitic cases presently studied. In this, 7 patients had only PMN count $>250 / \mathrm{mm}^{3}$, but culture negative for any organisms. Only 2 subjects were culture positive and isolated E. coli organism on culture by $72 \mathrm{hrs}$. In present study, the prevalence of SBP is found to be $18 \%$. Among this $18 \%$ ( 9 patients), 7 (77.7\%) were CNNA and 2 (22.3\%) were MNB.

In various studies, routine paracentesis has documented a prevalence of SBP of $10-27 \%$. Andreu et al reported a prevalence of $28 \%$, while Amarapurkar et al found it to be $22.5 \%$.

Mean age of the patients were 50.7 and mean age of patients diagnosed for SBP was 53.22. Dr. Dilshad Muhammad et al study showed mean age of whole of the population was found to be $51 \pm 12.49$ years.

In present study all the cases with abdominal pain, abdominal tenderness, altered sensorium were having SBP. So it is better to screen for ascetic fluid analysis in patients of cirrhosis with above complaints.

In present study, $87.5 \%$ of the 9 patients in the SBP group belonged to Child-Pugh class $\mathrm{C}$ and $6.25 \%$ to class $\mathrm{B}$. This finding supports the view that SBP is more common in patients with advanced liver disease. In a study by Amarapurkar et al had found that 6 of the 7 patients detected to have SBP belonged to class $\mathrm{C}(87.71 \%)$.

In present study, two MNB cases (22.22\%) were positive for E. coli which isolated in first 72 hours. In the study by Runyon et al, E. coli was responsible for $27.3 \%$ of cases of SBP and Staphylococcus aureus for $6.8 \%$. Ascitic fluid protein plays an important role in developing SBP in these patients.

In Runyon BA series, the patients with ascitic fluid protein $<1 \mathrm{gm} / \mathrm{dL}$ were more predisposed to development of SBP. Present study patients with ascitic fluid protein $<1 \mathrm{gm} / \mathrm{dL}$ are frequently predisposed to SBP as in the other series cited above.

\section{CONCLUSIONS}

- $\quad$ Cirrhotic cases with constitutional symptoms must be compulsorily screened for SBP and started on Antibiotic therapy to reduce the mortality.

- $\quad$ SBP being the problem in cirrhosis with ascites, all cirrhotics should be screened for SBP with at least ascitic fluid analysis, PMN cell count and culture of ascetic fluid.

- $\quad$ To maximize survival, it is important that paracentesis is performed in all patients with ascites at the time of hospitalization.

- So that infection can be detected and treated promptly. These patients must be treated with antibiotics aggressively, as they have poor prognosis and high mortality if not treated early.

The present study is taken up to find SBP in cases of ascites and find its aetiological causes, so that early diagnosis will help in early initiation of treatment of SBP leading to improvement of clinical state.

\section{REFERENCES}

1. Sola E, Gines P. Renal and circulatory dysfunction in cirrhosis: current management and future perspectives. J Hepatol 2010;53(6):1135-45.

2. Garcia-Tsao G. Spontaneous bacterial peritonitis. Gastroenterol Clin North Am 1992;21(1):257-75.

3. Hirayuki Enomoto, Shin-ichi Inoue, Akio Matsuhisa, et al. Diagnosis of spontaneous bacterial peritonitis and an in situ hybridization approach to detect an unidentified pathogen. Int J Hepatol Article ID 634617, 2014;pgs 7.

4. Runyon A. Ascites and spontaneous bacterial peritonitis. In: Feldman M, Friedman LS, Brandt LJ, eds. Sleiseinger and fordtran's gastro intestinal and liver disease. Elsevier Publishers 2010; 9th edn:p 1530.

5. Runyon A. Ascites and spontaneous bacterial peritonitis. In: Feldman M, Friedman LS, Brandt LJ, eds. Sleiseinger and fordtran's gastro intestinal and liver disease. Elsevier Publications 2010; $9^{\text {th }}$ edn:page 1531.

6. Garcia-Tsao G. Current management of the complications of cirrhosis and portal hypertension: variceal haemorrhage, ascites, and spontaneous bacterial peritonitis. Gastroenterology 2001;120(3):726-48.

7. Llovet JM, Planas R, Morillas R. Short-term prognosis of cirrhotics with spontaneous bacterial peritonitis: multivariate study. Am J Gastroenterol 1993;88(3):388-92.

8. Toledo C, Salmeron JM, Rimola A. Spontaneous bacterial peritonitis in cirrhosis: predictive factors of infection resolution and survival in patients treated with cefotaxime. Hepatology 1993;17(2):251-7.

9. Mihas AA, Toussaint J, Hsu HS, et al. Spontaneous bacterial peritonitis in cirrhosis: clinical and laboratory features, survival, and prognostic indicators. Hepatogastroenterology 1992;39(6):520-2.

10. FolIo A, Llovet JM, Navasa M, et al. Renal impairment after spontaneous bacterial peritonitis in cirrhosis: incidence, clinical course, predictive factors, and prognosis. Hepatology 1994;20(6):1495-501. 
11. McHutchison JG, Runyon BA. Spontaneous bacterial peritonitis. In: Surawicz CM, Owen RL, eds. Gastroenterology 2014;146:1680.

12. Bhatnagar MK, Rawat N. To assess the role of serial ascitic fluid cell count in treatment of spontaneous bacterial peritonitis. J Assoc Physicians India 2006;53:350.

13. Rimola A, Garcia-Tsao G, Navasa M, et al. Diagnosis, treatment, and prophylaxis of spontaneous bacterial peritonitis: a consensus document. International Ascites Club J Hepatol 2000;32(1):142-53.

14. Sleiseinger and fordtran's gastro intestinal and liver disease, $9^{\text {th }}$ ed. page 2010, page 1534.

15. Sharad C Shah. Complications of cirrhosis. In API textbook of medicine. 2003; $7^{\text {th }}$ edn:614-6.

16. Jose' Such, Bruce A Runyon. Spontaneous bacterial peritonitis. Clinical Infectious Diseases 1998;27(4):66974.

17. Amarapurkar DN, Viswanathan N, Parikh SS, et al. Prevalence of spontaneous bacterial peritonitis. J Assoc Physicians India 1992;40(4):236-8.

18. Puri AS, Puri J, Ghoshal UC, et al. Frequency, microbial spectrum and outcome of spontaneous bacterial peritonitis in north India. Indian J Gastroenterol 1996;15(3):86-9.
19. Aamir Husain, Dilshad Muhammad, Aamir Husain, et al. Bacteriology of spontaneous bacterial peritonitis. Professional Med J 2007;14(4):551-5.

20. Runyon BA. Ascites in liver disease. In: Haubrich WS, Schaffner F, Berk JE, eds. Bockus textbook of gastroenterology. Philadelphia: WB Saunders Company, 1994; $5^{\text {th }}$ edn:2004-22.

21. Obstein KL, Campbell MS, Reddy KR, et al. Association between model for end-stage liver disease and spontaneous bacterial peritonitis. Am J Gastroenterol 2007;102:2732-6.

22. Runyon BA. Ascites. In: Schiff Leon, Schiff Eugene R. eds. Diseases of the liver. Philadelphia: JB Lippincott Company 1993; $7^{\text {th }}$ edn:990-1015.

23. Runyon BA. Monomicrobial nonneutrocytic bacterascites: a variant of spontaneous bacterial peritonitis. Hepatology 1990;12(4 pt 1):710-5.

24. Andreu M, Sola R, Sitges-Serra A, et al. Risk factors for spontaneous bacterial peritonitis in cirrhotic patients with ascites. Gastroenterology 1993;104(4):1133-8.

25. Jose Such, Bruce A Runyon. Spontaneous bacterial peritonitis. Clinical Infectious Diseases 1998;27:669-76. 